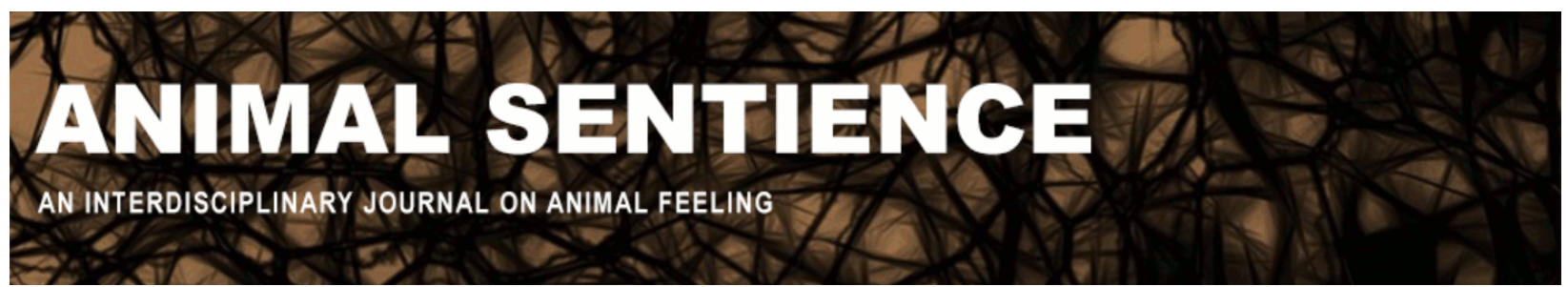

Attfield, Robin (2019) Futurity, selves and further organisms. Animal Sentience 27(4)

DOI: $10.51291 / 2377-7478.1532$

Date of submission: 2019-11-18

Date of acceptance: $2019-11-20$

(c)

This article has appeared in the journal Animal

Sentience, a peer-reviewed journal on animal

cognition and feeling. It has been made open access,

free for all, by WellBeing International and deposited

in the WBI Studies Repository. For more information,

please contact

wbisr-info@wellbeingintl.org.

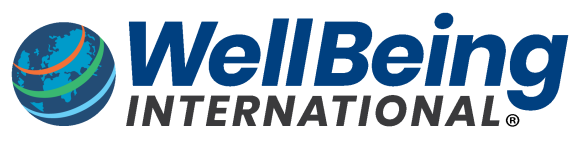

SOLUTIONS FOR PEOPLE, ANIMALS AND ENVIRONMENT 


\title{
Futurity, selves and further organisms
}

Commentary on Treves et al. on Just Preservation

\author{
Robin Attfield \\ Institute for Sustainable Places, Cardiff University
}

\begin{abstract}
Most aspects of Treves et al.'s target article are commendable, but I would suggest: explicitly including (1) Singer's 'equal interests' principle; adjusting (2) Mathews's principle of 'bioproportionality'; and clarifying the implications of (3) Parfit's Non-Identity Problem, (4) the limits of present predictions of future needs, and (5) the application of the concept of selves to biotic individuals. There is also a problem about (6) how plants are to be individuated.
\end{abstract}
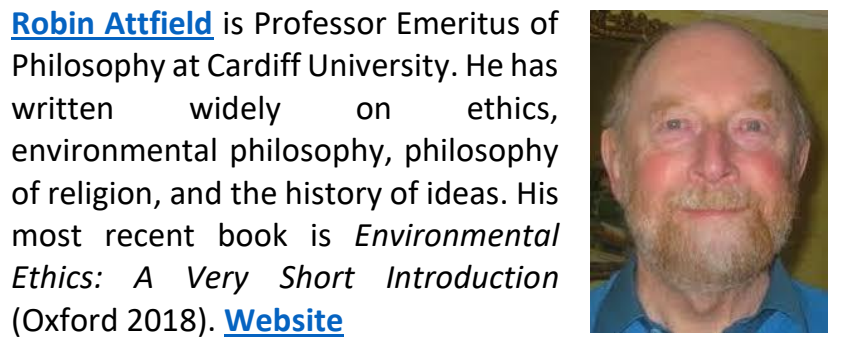

Treves et al. (2019a,b) are, in my view, right on virtually all their main points. Justice has to be seen as involving non-humans as well as humans. Conventional conservation is prone to ignore non-humans, as do ethicists who study future generations, but really only mean future human generations. Many who profess to being non-anthropocentrists come close to anthropocentrism in giving priority to human interests (in a 'Greater Value' stance). Nonhuman individuals should not be disregarded in a focus on species or on ecosystems. Institutions need to be devised to adjudicate between the potentially competing interests of current adults, youth, current non-humans, future human generations and future non-human generations. The suggestion should be taken seriously that courts (presumably one in each country) ought to undertake this role, with legislatures restructured to enable them to carry through such adjudications.

Treves et al.'s stance could benefit from a few refinements: Singer's (1993) principle that equal interests count equally (and greater interests count for more) needs to be included in the system of priorities more explicitly. The scope of this principle also needs to be expanded so that it applies not only to sentient creatures but to non-sentient ones as well. At the same time, the principle of bioproportionality (Mathews, 2016), which seeks to partition planetary resources equitably among species, needs either to be clarified or discarded. It might be less problematic if resources were simply water and soils. But for interacting species such as hares and lynxes, relevant resources for each species include the other. In many ecosystems, species need many of the same resources as well as the continuation of those ecosystems so that the other species can continue to flourish. Once this is realised, the notion of partitioning planetary resources between species no longer makes sense.

Treves et al.'s treatment of futurity does not discuss Parfit's (1971) Non-Identity Problem and its implications. We cannot treat in the same way the identifiable individuals (such as current humans and non-humans, and who have already been conceived), and those future people and other animals whose identities are currently unknowable, and to whom we 
therefore cannot have direct duties. We certainly can include unidentifiable future individuals within the category of 'whoever will live' (in certain decades or centuries); but our ability to predict their interests is liable to be less steady and weaker. What we have to focus on is the needs that those possible beings will have if they come into existence (see Attfield, 2014, 2015). But once this is acknowledged, the role of adjudication has to be seen differently from, for example, providing for existing creatures in their later years.

One related matter concerns the individuals so far into the future that very little beyond their natural kind can be predicted about their needs and treatment. We can have regard for those creatures who will live after the demise of humanity. But the needs of creatures living at times when climate change has increased average temperatures by (say) ten degrees become almost entirely unpredictable. In my view, the limits of justice (indeed of ethics) coincide with the limits of generic predictability. This probably means they lie tens of thousands of years hence, not millions of years hence. If Treves et al. agree, then the scope of adjudication between the interests of different creatures would be materially affected, and their stance would need to be modified accordingly.

A related issue arises from Treves et al.'s decision to treat all biotic individuals as selves, between whose interests adjudication is required. The problem here is that the notion of a self is standardly associated with individuals with attitudes, perspectives and points of view of their own. Some philosophers have actually denied the moral standing of all other creatures, suggesting that things cannot go better or worse for them (Feinberg, 1974). This suggestion strikes me as erroneous, because the absence of a perspective does not mean that the creature in question lacks a good of its own, which can flourish or wither (Attfield, 1981). But the decision to regard individuals as selves could mean that all those individuals without their own perspective are excluded from the circle of justice, thus reinstating the very limitations of sentientism that Treves et al. almost certainly wish to transcend.

Even if Treves et al. were to accept that all living organisms are selves, and that the absence of a perspective does not abrogate this status, there remains a problem of individuation among such modular beings as plants. Many plants, ranging from banyan trees through gooseberry bushes to spider-plants, can be counted in different ways, depending on whether their off-shoots, once they have taken root, count as distinct plants or as components of the parent plant. This problem, when practical matters are encountered, requires at least some provision against double-counting. Although 'futurity' is likely to be in the majority, there is a danger of over-estimating the extent of that majority unless this problem is addressed.

The need for these clarifications or revisions suggests that 'Just Preservation' needs to be given book-length treatment, rather than confined to an article. The problems may well be addressable, but in my view, they are yet to be addressed. Congratulations are nevertheless to the authors for achieving such extensive progress.

\section{References}

Attfield, R. (1981) The good of trees. Journal of Value Inquiry, 15, 35-54

Attfield, R. (2014) Environmental Ethics: An Overview for the Twenty-First Century (2 ${ }^{\text {nd }}$ ed.). Cambridge: Polity

Attfield, R. (2015) The Ethics of the Global Environment ( $2^{\text {nd }}$ ed.). Edinburgh: Edinburgh University Press 
Feinberg, J. (1974) The Rights of Animals and Unborn Generations. In W.T. Blackstone (Ed.), Philosophy \& Environmental Crisis. Athens, GA: University of Georgia Press

Mathews, F. (2016) From biodiversity-based conservation to an ethics of bio-proportionality. Biological Conservation, 200, 140-148

Parfit, D. (1971) Personal identity. The Philosophical Review, 80(1), 3-27

Singer, P. (1993) Practical Ethics. Cambridge: Cambridge University Press

Treves, A., Santiago-Ávila, F. J. and Lynn, W. S. (2019a) Just preservation. Biological Conservation, 229, 134-141

Treves, A., Santiago-Ávila, F. J. and Lynn, W. S. (2019b) Just preservation. Animal Sentience 27(1) 